\title{
The Other in Science Fiction as a Problem for Social Theory ${ }^{1}$
}

\author{
Vladimir Bystrov \\ Doctor of Philosophical Sciences, Professor, Saint Petersburg University \\ Address: Universitetskaya Nabereznaya, 7/9, Saint Petersburg, Russian Federation 199034 \\ E-mail: vyb83@yandex.ru \\ Vladimir Kamnev \\ Doctor of Philosophical Sciences, Professor, Saint Petersburg University \\ Address: Universitetskaya Nabereznaya, 7/9, Saint Petersburg, Russian Federation 199034 \\ E-mail: kamnevvladimir@yandex.ru
}

\begin{abstract}
The paper discusses science fiction literature in its relation to some aspects of the socioanthropological problem, such as the representation of the Other. Given the diversity of sci-fi genres, a researcher always deals either with the direct representation of the Other (a creature different from an existing human being), or with its indirect, mediated form when the Other, in the original sense of this term, is revealed to the reader or viewer through the optics of some Other World. The article describes two modes of representing the Other by sci-fi literature, conventionally designated as scientist and anti-anthropic. The scientist representation constructs exclusively-rational premises for the relationship with the Other. Edmund Husserl's concept of truth, which is the same for humans, non-humans, angels, and gods, can be considered as its historical and philosophical correlate. The anti-anthropic representation, which is more attractive to sci-fi authors, has its origins in the experience of the "disenchantment" of the world characteristic of modern man, especially in the tragic feeling of incommensurability of a finite human existence and the infinity of the cosmic abysses. The historical and philosophical correlate of this anti-anthropic representation can be found in Kant's teaching of a priori cognition forms, which may be different for other thinking beings. The model of an attitude to the Other therefore cannot be based on rational foundations. As a literary example where these two ways of representing the Other are found, we propose the analysis of The Martian Chronicles by Ray Bradbury, which, on the one hand, offers the fictional extrapolation of the colonization of North America and the inevitable contacts with its indigenous population. On the other hand, The Martian Chronicles depicts a powerful and technologically advanced Martian civilization, which disappears for some unknown reason, or ceases to contact the settlers. The combination of these two ways of representing the Other allows Bradbury to effectively romanticize and mystify the unique historical experience of colonization, thus modifying the Frontier myth.
\end{abstract}

Keywords: science fiction, the Other, monster, representation, scientism

\section{Multiple Realities and Science Fiction}

Alfred Schutz elaborated one of his most widely known and still-intriguing and promising ideas in his 1945 essay "On Multiple Realities", and discussed it later in several papers quite persistently. The very idea, related to the notion of the sub-worlds or sub-universes

1. This paper was supported by The Russian Foundation for Basic Research. Project № 19-011-00779 "Illiberal Concepts of Tolerance: History, Practice, and Perspectives". 
of the encompassing universe, had been originally proposed by William James in more psychological terms. Schutz, as a phenomenologist, preferred to call these universes finite provinces of meaning, "each of which may be conceived as reality after its own fashion" (1976: 229). He continued by writing that "Hence we call a certain set of our experiences a finite province of meaning if all of them show a specific cognitive style and are-with respect to this style-not only consistent in themselves but also compatible with one another" (230). The world of fantasy can be seen as such a province. However, Schutz was definitely prone to use the plural instead of the singular; "fantasy worlds", he wrote, "since it is a question not of a single but rather of several finite provinces of meaning. Although, in direct contrast to the life-world, they appear to be closely related to one another, since they all bracket determinate strata of the everyday life-world, they are nevertheless heterogeneous and not mutually reducible" (1974: 28). Schutz, as far as we know, never paid attention to or even mentioned the world of sci-fi as a special sub-sub-universe in this large and diversified province of meaning. It would be reasonable to do it now by following him on his way, not only pointing to the large provinces of meaning but also separating the sub-universes in the world of fantasy. However, it is difficult and hardly possible to indicate what sci-fi, not as a mere collection of works of literature, art, and cinema but as a world, is.

Classifications of SF genres often seem to reduce the description of the field to simple enumerations of its sub-genres, without any governing principle at the basis. George Mann, in his Mammoth Encyclopedia $(2001: 163)^{2}$, frankly confesses that

... SF, by necessity, is an open and wide-ranging genre whose definition can have as much to do with the way in which a book is written as with its content. It also incorporates the more fantastical Space Opera, which, although it has its proponents who insist on claiming a "scientific" foundation for the intergalactic conflicts and militaristic alien invasions, for the most part prefers to concentrate on the end result-spectacular action-rather than the means-convincing extrapolation. This inclusiveness makes any binding definition hazardous ...

He nevertheless attempts a kind of descriptive definition that in no way reveals anything about the meaningful unity of sci-fi-he writes (Ibid.: 167-169):

SF is a form of fantastic literature that attempts to portray, in rational and realistic terms, future times and environments that are different from our own. It will nevertheless show an awareness of the concerns of the times in which it is written and provide implicit commentary on contemporary society, exploring the effects, material and psychological, that any new technologies may have upon it. Any further changes that take place in this society, as well as any extrapolated future events or occurrences, will have their basis in measured and considered theory, scientific or otherwise. SF authors will use their strange and imaginative environments as a testing ground for new ideas, considering in full the implications of any notion they propose.

2. Since we have access only to the Kindle Edition of this book, we refer here to Kindle locations instead of page numbers. In this quotation, italics are added. 
These arguments sound reasonable and, in a sense, are very useful for those who try, as we are going to do in this paper, to trace the line between the imagined worlds of sci-fi and the real world where these imagined worlds were created. What is disturbing, nevertheless, is the variety of the keywords for the genres Mann mentions: alien, alternative world, alternative reality, android, anti-gravity, antimatter, artificial environment, artificial intelligence, biotechnology, black hole, cloning, comic SF, crime, cryonics, cyberpunk, cyberspace, dimensions, Dyson sphere, dystopia, ecology, eugenics, evolution, far future, future history, gender, generation starship, genetics, hard SF, hardware, horror, humanist SF, militaristic SF, nanotechnology, near future, overpopulation, planets, political SF, post-apocalyptic SF, science fantasy, scientific romance, shared world, soft SF, space opera, space travel, stars, steampunk, terraforming, time, transcendence, utopia, and virtual reality.

The same can be said about the Encyclopedia written by Don D'Amassa. For him, "[s]cience fiction is one of the three subdivisions of fantastic literature, the other two being fantasy fiction and supernatural horror. Although definitions vary and some individual works may blur the distinction between one branch and another, most fantastic or speculative stories and novels can-by general consensus-be placed in one of the three categories" (D'Amassa, 2005: iv). Here we see even less unity in the descriptions. D'Amassa mentions the following sub-genres: alternate history, change war, cyberpunk, dystopian, first contact, future history, gestalt, hard science fiction, lost race, military science fiction, near future, parallel world, psi powers, sentience (artificial intelligence systems), shapeshifter, sharecropping, soft science fiction, space opera, terraform, time travel paradox, uplift, utopian novel, and we should admit that it is probably the shortest list (2005).

This valuable list, as in the previous case, is evidently not a scientific classification, and fails to demonstrate logical coherence based on a "general consensus". We offer our own list of sci-fi topics, perhaps more consistent but not so extensive:

- hard fiction, where the center of a storyline is formed by the theme of the conquest of space (not exclusively of the outer cosmic space, but also, for example, of the unexplored Earth territories, the ocean depths, etc.) by means of as-yet-unknown scientific and technological discoveries;

- chronofiction, i.e., time travel;

- social utopias and dystopias, including apocalyptic and post-apocalyptic fiction, through which social and political regimes of future societies are modeled;

- contact with alien civilizations resulting in both technical and cultural mutual enrichment and military conquest;

- parallel worlds, including alternative history and steampunk fiction;

- cyber-fiction, artificial intelligence, androids, replicants, and cloning;

- the enhancement (by means of scientific and alternative technologies) of hidden human abilities.

We can see that some of these sub-genres are directly related to various aspects of a sociological and anthropological problem known as the "representation of the Other". 
Among the examples might be alien contact, or the relationship between a human being and an android, but a closer look will allow the same idea to be extended to all other subgenres. Indeed, in all cases, we are dealing either with a direct representation of the Other (a being other than human) or with its mediated form revealing the Other World to the reader or viewer, and through this World, the Other, in the original sense of the term.

It should be stressed that we are not talking about any special sci-fi works, such as those that critics in the US and England call "anthropological science fiction" (Clute, Nichols, 1993a: 41-43). Such literary pieces as No Enemy but Time (1982) and Ancient of Days (1985) by Michael Bishop, Rite of Passage (1954), Field Expedient (1955), and Between the Thunder and the Sun (1957) by the professional anthropologist Chad Oliver, or The Word for World is Forest $(1972 ; 1976)$ by Ursula K. Le Guin (anthropologist Alfred Kroeber's daughter) constitute a "speculative anthropology" which does not have any parallels in scientific writings since it depicts humans as they might have been. Besides, there are also works obviously dominated by the topics of multiculturalism, racial or gender equality, and tolerance, including Octavia Butler's Xenogenesis collection, Iain Banks' series of novels called Culture, or The Expanse, a literary cycle by James S. A. Corey along with the eponymous television series. We argue that this representation of the Other in sci-fi is not limited only to these and similar writings; we affirm it to be the characteristic of any literary text in the genre. It is this representation that constitutes the unavoidably essential feature of the genre.

The SF universe is inhabited by a variety of creatures, human-like and non-human, friendly and aggressive, lagging developmentally behind the earthlings, or, on the contrary, being well ahead of them. It might seem that this alone is enough to conceive of the diversity of the SF universe as an extrapolation of the ethnic, religious, and cultural diversity of contemporary mankind. The models of coexistence in the Universe would then be the models for the possible construction of relations between various civilizations, and models for the optimal solution of political, religious, and other conflicts. Given the specific nature of the SF audience, i.e., the fact that the most part of its readers and viewers are teenagers and young people, we can argue that among the most important tasks of SF is the task of education and upbringing consisting in the formation of specific patterns of thinking and behavior for the contemporary world. In other words, SF literature shapes the tolerance myth, which prepares humans for a decent life in a new, poly-centric world (Salnikov, 2017).

This understanding of SF clearly explicates the historical time for the emergence and propagation of this kind of literature. Globalization processes that unfolded in the twentieth century led to a religious unification and a weakening of traditional forms of consolidation. The concept of tolerance, previously associated mainly with practices of religious toleration, is now gradually expanding its scope to include such issues as racial, age and gender inequality, post-colonialism, multiculturalism, sub-alternity, minority identities, etc. This expansion takes place both in theoretical concepts and practices designed to deal with new conflict situations. Surely the theoretical justification for this new idea of 
tolerance is not limited to academic treatises but is accompanied by a wide-ranging thematization of the Other, including the art forms provided by the sci-fi genre. ${ }^{3}$

The main theme is surely devoted to the stories of interplanetary communication, but in fact, all branches of sci-fi can legitimately be regarded as types of artistic representation of the relation towards the Other. Some features of the sci-fi genre render these representations extremely effective. First, SF as a reflection and representation of a new (not typical for an ethnically-consolidated society) attitude towards the Other always has the "sanction" of conventionality, which allows to avoid the direct accusations brought forward by religious and other forms of conformism; secondly, SF not only reflects this new attitude towards the Other, but also is the tool of its verification and social promotion. This tool is more effective than academic theories for it reaches a much wider audience; this audience is a specific segment of society (youth and teenagers) who have not yet developed a critical attitude towards the information they receive, who are characterized by "genetic" non-conformism, a tendency to reject everything outdated just because it is so, and to accept everything new just because it is new.

There might be an objection that any fantasy fiction, if it is, as defined by Darko Suvin, “... a literary genre whose necessary and sufficient conditions are the presence and interaction of estrangement and cognition" (Clute, Nichols, 1993b: 313), or is a representation of the Other (an other sentient being, an other world, etc.). In the same way that the uniqueness of sci-fi genre can be reduced to some "fairy tale reality" (to which "the spirit of science" or "scientific attitude" is attached) (Neelov, 2008), the ways in which the Other is represented in SF are identical to all three derivations of fairy tale folklore, the literary fairy tale, fantasy, and science fiction. Indeed, the above list of SF sub-genres would seem to argue in favor of the maximum stretching of the chronological boundaries of fantasy literature since travels to unexplored lands, to distant planets, and contacts with their inhabitants have been depicted since antiquity. However, From the Earth to the Moon: A Direct Route in 97 Hours, 20 Minutes by Jules Verne and The First Men in the Moon by Herbert Wells are genuine SF works. This definitely cannot be said about $A$ Voyage to the Moon by Cyrano de Bergerac, though the techniques of interplanetary travel described in all these three writings are very far from any scientific probability.

The problem of SF chronological boundaries has a direct relevance to the question of representing the Other, since the question of whether its mode is fantastical or realistic is always determined by social and cultural context of a particular historical period. Neelov continues by saying, ". . . the novel Twenty Thousand Leagues Under the Sea by Jules Verne belongs to hard science fiction, but its fantasy will never find its real embodiment since Captain Nemo's 'Nautilus' is sailing in the ocean of the nineteenth century and it is on this linking of unlikable (and not on the submarine's image, which originally is not fantastic at all) that the novel's fantasy is constructed" (2008: 103). Now, we will try to describe the two most typical modes to represent the Other as proposed by sci-fi literature.

3. Cf. on the general problem of the Other in social theory Bankovskaya (2007). 
We may roughly define the first way as the scientist one since it is based on the idea of the dominant role of scientific worldview and generally remains within the boundaries of the definition of "scientifiction" as given by H. Gernsback (1926: 3):

By "scientifiction" I mean the Jules Verne, HG Wells ... type of a story-a charming romance intermingled with scientific fact . . . Not only do these amazing tales make tremendously interesting reading-they are always instructive. They supply knowledge that we might not otherwise obtain-and they supply it in a very palatable form. For the best of these modern writers of scientifiction have the knack of imparting knowledge, and even inspiration, without once making us aware that we are being taught.

Gernsback emphasizes that scientifiction is an essentially new art form, which (before Edgar Allan Poe and Jules Verne) simply could not exist previously (Ibid.):

It must be remembered that we live in entirely new world. Two hundred years ago, stories of this kind were not possible. Science, through its various branches of mechanics, electricity, astronomy, etc., enters so intimately into all our lives today, and we have become rather prone to take new inventions and discoveries for granted. Our entirely mode of living has changed with the present progress, and it is little wonder, therefore, that many fantastic situations-impossible 100 years ago-are brought about today. It is in these situations that the new romancers find their inspiration

There is a certain similarity between Soviet literary criticism (leaving aside its ideological rhetoric) and Gernsback's understanding of scientifiction's specific nature. B. Mikhailovsky, the author of the "Fantastic Fiction" entry in The Literary Encyclopedia of 1929-1939, proposed to distinguish between a materialist fiction (as written by J. Swift, N. Gogol, M. Saltykov-Shchedrin, or V. Mayakovsky) and an idealist fiction (A. Strindberg, or G. Huysmans), defining the status of "science fiction" (he uses quotation marks) as follows (1939: 585):

The conventional nature of "science fiction" is clearly manifest in Edgar Poe, sometimes in Herbert Wells; in Jules Verne it might be veiled by scientist language. However, in other cases the artist's hypothesis and technological or scientific foresight are so close to each other, the degree of artistic conventionalism and deviation from likelihood are so slight that the work ceases to be perceived as fiction and goes beyond it, into the realm of credible prediction (Jules Verne's submarine, hydroplane, etc.). It should be kept in mind that utopia, whether technological or social, can be constructed not only on "real possibilities", but also on "abstract, formal, empty possibilities" (Hegel). On the basis of such "empty possibilities" Wells has sometimes misinterpreted the prospects of social history in idealist and reactionary terms (degeneration of humankind under socialism, etc.). 
In other words, for the Soviet ideological orthodoxy, science fiction was the realm of artistic hypotheses, scientific foresight, and descriptions of technical inventions which, due to relentless logic of scientific and technical progress, should arise in the nearest future. We just want to emphasize it now: scientific ideas, technical imagination should find their place in the science fiction. One could even imagine the consequences of technical innovation in socialist and capitalist societies. However, any extrapolation of "science fiction" as understood in this way into the field of social forecasting was seen as politically rather unreliable, since the communist future as a form of social organization of humanity could not be discussed. It was the best and it was inevitable in only one universal form. There was no place for fantasy and fantastic in this realm.

\section{"Truth is One and the Same": Ivan Efremov meets Edmund Husserl}

The technological and scientist attitude can be found in the works of the founders of the Soviet version of science fiction. For them, sci-fi was a new literary genre that had no parallels in the past. Ivan Efremov (1908-1972), one of the most influential writers and thinkers of his time, once formulated (1971:5) that

... science fiction is a product of our century, and it is sharply different from pure fiction, fairy tales or other types of previous literature, it is not akin to any works of the past. What is the basis of science fiction? Where is the criterion for distinguishing it from other types of literature? Only in one thing: in attempt at scientific explanation of the phenomena described, in revealing causality by scientific methods, without referring to a mysterious destiny or the will of the gods. As soon as religion ceased to satisfy the intellectual, science took up its place in his general outlook. There could be no emptiness here for a thinking, intelligent being. This gave inevitable rise to a special type of literature where the explanation of incentives and accidents, morals and goals was abandoned not to empirical observation, not to a mysterious combination of circumstances, but to the regularities of world structure, society, and historical development. This path requires from the wordsmith huge erudition, discovery of new ways in the analysis of real-life situations, pursuit of other means of expression.

It is this fundamental scientism that predetermined Efremov's attitude towards Ray Bradbury, his great American contemporary, whose writings, he believed, were wrongly attributed to sci-fi, but were in fact testimonies to his distrust in science and its achievements and his disbelief in its positive impact on humanity. In his later writings, Efremov modified his views. In a large narration of The Bull's Hour, he contemptuously mentioned the "antlike false socialism in China", and described "another future" for a part of the mankind that admittedly left the Earth on the eve of the great era of cosmic expansion and organized another form of political civilization somewhere. Their names would seem "Chinese" for an untrained reader, ${ }^{4}$ but they could not overcome their technological

4. It was the time of the most acute conflicts between the Soviet Union and Mao Zedong's People's Republic of China. However, semiofficially, the book was estimated as politically suspect and even as a hidden parody of the Soviet regime. It was removed from public libraries near the end of the 1970 . 
backwardness as compared with the Earth, etc. However, it was an attempt to demonstrate another possible (dead-end) human future.

A scientist representation of the Other in most of his earlier writing is remarkably optimistic and allows for a variety of intelligent life-forms in the SF universe, which can only confirm the efficiency of this model of relating to the Other. The sci-fi universe is being inhabited according to certain logical patterns, and contacts between earthlings and the inhabitants of exo-planets are effective when these patterns are understood and strictly observed. All inhabitants of exoplanets pass in their development through the Era of Disunity, the Era of World Unity, the Era of Common Labor (it consists of the Ages of Simplification, Realignment, the First Abundance, and Cosmos), and the Great Circle Era (2016). At this last stage, civilizations forming a galactic alliance start to exchange their scientific and technological advances by means of radio communication. Much of this information still remains incomprehensible to earthlings since some Great Circle civilizations are millions of years ahead of our planet, but the heroes of Efremov's Andromeda Nebula have no doubt that these achievements will also be mastered due to the unity of historical development (and the efficient operations of the "Memory Machines").

The fact that this galactic progression is based on the general laws of logic and mathematics is not questioned by anyone. Trying to contact with the creature discovered on the exo-planet, the captain of the Earth's spaceship draws "Pythagoras' Trousers" in the sand, because all sentient beings should understand geometry since its laws are the same for our entire Universe (Gurevich, 1968). A starship crew sends out radio messages containing Mendeleev's Periodic Table to distant exo-planets, believing that rational beings of any species will necessarily comprehend its contents (Snegov, 2010). Based on the unity of mathematical principles (in the sense that there can be no different mathematics since mathematics is one and the same), the engineer from our planet, having at his disposal the time traveling device left by aliens, creates a similar machine, while at the same time fixing some shortcomings of the replicated prototype. He is convinced that whatever the highest level of development that electronics and cybernetics may have reached in the alien world, their foundations are inevitably the same. Mathematics and logic cannot differ and therefore the mind of space aliens is identical to the mind of earthlings (Martynov, 1966).

All this cannot but remind us of Edmund Husserl's famous formula: "What is true is absolutely, intrinsically true: truth is one and the same, whether men or non-men, angels or gods apprehend and judge it. Logical laws speak of truth in this ideal unity, set over against the real multiplicity of races, individuals and experiences, and it is of this ideal unity that we all speak when we are not confused by relativism" (2001: 79). But while grasping this uniform truth, Husserl sets up a certain hierarchy (Ibid.: 95):

As adults stand to children, as mathematicians stand to us laymen, so a higher species of thinking beings, e.g., of angels, could stand to men. Such words and concepts have no achievable sense for us, since certain peculiarities of our mental constitution stand in the way. A normal man takes about five years to understand the theory of Abelian functions or even to grasp its concepts. It might be the case that a mil- 
lennium would be needed for a humanly constituted being to grasp angelic functions, though he can hardly hope to live as long as a century. But such an absolute unattainability, rooted in the natural limits of a specific constitution, would not be the one that absurdities and senseless statements offer.

Here we can see the possible collision of the human mind with two types of contradictions: in the first case, what we are still not capable of comprehending will seem contradictory and incomprehensible to us; in the second case, we will perceive things as contradictory since they are naturally so. In this second case, our mind is equal to the minds of non-humans, angels, and gods, for they also cannot but face such contradictions. Angels engaged in mathematics may use other methods of comprehending mathematical truths, but their foundations and theorems are identical to ours. Angels or extraterrestrial creatures, as well as the members of the Great Circle, will be dealing with the same mathematics. The idea might seem strange, but it was quite natural for those who organized missions of the automatic spacecrafts Voyager 1 and Voyager 2 to meet nonhuman civilizations somewhere in deep space: they engraved mathematic formulas and drawings on golden plates, being inspired, as we dare to admit, not only by their sciences, but also by the hard science fiction of their youth.

\section{The Universe Disenchanted: Max Weber visits the Space Opera}

We shall roughly call the second mode of representing the Other in sci-fi literature anti-anthropic. Here, it is important to emphasize that the mere depiction of sentient beings or monsters does not form a sufficient basis for attributing such sci-fi works to the anti-anthropic mode of representing the Other. In those works, where the first scientist mode is clearly dominant, one can find hippos from Aldebaran, arachnids from Altair, or snake-men from Vega (Snegov, 2010). Their contacts with earthlings, though highly problematic, are universally valid in every mathematically possible world. Even if mankind encounters a clearly hostile extraterrestrial civilization, it turns out that this hostility is caused exclusively by social conditions, for example, by a political regime based on tyranny, while the common ground of rational mathematical foundations is, on the contrary, the key to reconciliation and cooperative action. ${ }^{5}$

5. In the third part of his trilogy Men as Gods, Sergey Snegov narrates the story of the Ramirs civilization, which is superior to humanity in its capabilities (both technical and mental), but the attempts of earthlings to contact them are met either with hostility or indifference. At the end of the story, the protagonist comes to a guess that the attempts of contact were used by the Ramirs for their own purposes, as part of an experiment where earthlings were assigned the role of experimental ants or rabbits. A similar form of representing the Other is described by Clifford Simak in the story called Immigrant, where a more developed civilization organizes something like school-lessons for earthlings with outstanding abilities. In both cases, a rational explanation of the actions of a more developed civilization proves to be inaccessible to earthlings, but there is no doubt that these actions have, nevertheless, a rational basis. Such sci-fi plots can be viewed as a correlate of religious and philosophical providentialism, as the Bible's passage of "... not a single hair will fall from the head of a person without the will of God" to Hegel's "cunning of the world Reason"-where the rationality of higher powers is postulated, but the foundations of this rationality are obviously hidden from ordinary human understanding. 
The distinctive feature of this anti-anthropic mode of representing the Other is associated not with external manifestations of SF works, which could be objectified, but with their inner side with what can be called the specific message of this genre. The sci-fi message, in turn, is a reflection and crystallization of certain social processes and radical changes in the European mentality, defined by Max Weber as the "disenchantment of the world". Weber characterizes the world of European modernity by the process of "intellectual rationalization", but points out that this rationalization does not necessarily mean that modern man, unlike primitives, has more knowledge about the conditions of his existence. According to Weber (2008: 35), this rationalization means something different:

It means the knowledge or belief that if we only wanted to we could learn at any time that there are, in principle, no mysterious unpredictable forces in play, but that all things-in principle-can be controlled through calculation. This, however, means the disenchantment of the world. No longer, like the savage, who believed that such forces existed, do we have to resort to magical means to gain control over or pray to the spirits. Technical means and calculation work for us instead.

Thus, the "disenchanted" world is a calculated world, and it is well known that the word ratio also has, among other things, the meaning of "calculation". ${ }^{6}$ At the same time, the ideal of scientific knowledge in modern societies is inextricably linked to the "exact" sciences, where accuracy is ensured by the use of a mathematical apparatus, that is, by means of "calculation". Calculation, according to Weber, replaced modern man's appeal to magic or spiritual prayers, and that is why he uses the term "disenchantment of the world". Here one can find a direct clue to the mentality that is reflected in sci-fi. In many regards, it accounts for the popularity of this genre. The very name of the genre-science fiction-perfectly conveys the dual, intermediate, or transitional nature of this mentality; science indicates the completeness of "intellectualistic rationalization", fiction is the preservation of a magical view of the world. To assert, as Ivan Efremov does in the above sci-fi definition, that the element of fiction plays a role strictly subordinate to a scientist "rationalization" of the world, means, as the history of the genre has shown, a substantial impoverishment of its subject matter, that is, a simplification of its diversity. The spirit of SF presupposes the maintenance of a balance between these two elements. However, the achievement of this balance, which should ideally approach harmony, is significantly complicated not so much by the questionable "rationalization" of fiction, but by the fact

6. In pre-modern societies, the prospect of universal calculation was well known and feared, as evidenced by the numerous citations of Verses 25-27 from the Book of Daniel ("God has numbered your kingdom, and finished ... You have been weighed in the balances, and found wanting ... Your kingdom has been divided"), interpreted as a prediction of imminent death (of the individual or society as a whole). Calculation is understood in traditional societies as an omen of imminent doom: "Much could be said about the prohibitions formulated in certain traditions against the taking of censuses . ..., if it were to be stated that such operations .... have among other inconveniences that of contributing to the cutting down of the length of human life, but the statement would simply not be believed; nevertheless, in some countries the most ignorant peasants know very well, as a fact of ordinary experience, that if animals are counted too often far more of them die than if they are not counted; but in the eyes of moderns who call themselves 'enlightened' such things cannot be anything but 'superstitions"' (Guenon, 1972: 144). 
that the magical relation retained here is a relation to the world already "disenchanted", to the world, after the words of Friedrich Hölderlin, out of which "the gods have gone". The visible image of the "disenchanted" world is a cosmic abyss, its scale disproportionately huge if compared to the human dimension, and was gradually disclosed through the destruction of the previous methods for the domestication of the inhuman universe such as geocentric illusions, the attempts to build constellations out of chaotic clusters of stars, or to relate the movement of heavenly bodies to the vicissitudes of human destiny, and so on. The dramatic experience of the inhumanity of the Universe, which, nevertheless, remains the only human abode, is sci-fi's keynote which is so obvious and undeniable that it is easily forgotten not only by critics looking for a precise definition of the genre, but even by sci-fi authors themselves.

\section{Transcendental Aesthetics and the Black Abyss of Cosmic Horror: Kant and Lovecraft}

The same dramatic experience may be discovered in Kant's famous statement concerning the harmony between the starry sky overhead and the moral law residing in the depths of the human soul. This statement is mostly understood in the sense that moral law is just as amazing as cosmic harmony. Indeed, a moral law is impossible without at least three premises, each completely implausible. As one may know, what is necessary is the absolute freedom of human choice between good and evil, for if this freedom is limited by some thing (by external coercion, or by human nature itself), then human beings will not be able to perform actions due to their free choice, whereas moral law is based on freedom. Additionally, human immortality is necessary, since it alone can ensure the triumph of the retribution principle whose absence turns the moral law into mere wishful thinking. Finally, only the existence of an Almighty God can guarantee the availability of the first two premises. Therefore, the moral law is as amazing as the harmony of the starry sky.

However, if we quote Kant in full (2002: 203), something else is revealed:

Two things fill the mind with ever new and increasing admiration and reverence, the more frequently and persistently one's meditation deals with them: the starry sky above me and the moral law within me. Neither of them do I need to seek or merely suspect outside my purview, as veiled in obscurities or [as lying] in the extravagant: I see them before me and connect them directly with the consciousness of my existence. The first thing starts from the place that I occupy in the external world of sense and expands the connection in which I stand into the immensely large, with worlds upon worlds and systems of systems, and also into boundless times of their periodic motion, the beginning and continuance thereof. The second thing starts from my invisible self, my personality, and exhibits me in a world that has true infinity but that is discernible only to the understanding, and with that world (but thereby simultaneously also with all those visible worlds) I cognize myself not, as in the first case, in a merely contingent connection, but in a universal and necessary one. The first sight, of a countless multitude of worlds, annihilates, as 
it were, my importance as an animal creature that, after having for a short time been provided (one knows not how) with vital force, must give back again to the planet (a mere dot in the universe) the matter from which it came. The second sight, on the contrary, elevates infinitely my worth as that of an intelligence by my personality, in which the moral law reveals to me a life independent of animality and even of the entire world of sense, at least as far as can be gleaned from the purposive determination of my existence by this law, a determination that is not restricted to conditions and boundaries of this life but proceeds to infinity.

It is clear that Kant does not unite the starry sky and moral law, but opposes them, and does so twice. The second opposition is particularly consonant with what we have said above: the starry sky "annihilates ... my importance as an animal creature that ... must give back again to the planet (a mere dot in the universe) the matter from which it came". The enormous scale of this annihilation where the human being is endowed with a gift of life only for a moment and then gives it back to the planet, which is no more than a point in the universe-as well as a shocking perception of infinity, of worlds over worlds and systems over systems, - saturates this hypnotic image with pathetics similar in tonality with the famous confession of one of the founders of science fiction in America, Howard Phillips Lovecraft (2005: 167): ${ }^{7}$

The most merciful thing in the world, I think, is the inability of the human mind to correlate all its contents. We live on a placid island of ignorance in the midst of black seas of infinity, and it was not meant that we should voyage far. The sciences, each straining in its own direction, have hitherto harmed us little; but some day the piecing together of dissociated knowledge will open up such terrifying vistas of reality, and of our frightful position therein, that we shall either go mad from the revelation or flee from the deadly light into the peace and safety of a new dark age.

The analogies between Kant's agnosticism and Lovecraft's merciful ignorance are thoroughly explored in the book written by a prominent contemporary philosopher, Graham Harman (2012). We should note right away that in the already mentioned text, Lovecraft speaks not only of the black seas of infinite outer space, but also of the depths of time that defy any rational calculation. He wrote that "Theosophists have guessed at the awesome grandeur of the cosmic cycle wherein our world and human race form transient incidents. They have hinted at strange survivals in terms which would freeze the blood if not masked by a bland optimism" (Lovecraft, 2005: 167). Evidently, Lovecraft refers to the four Yugas of Hinduism, whose duration is measured in tens of thousands of years, and which, in turn, form one era of Manu, or Manvantara. There are 14 such Manvantaras,

7. Lovecraft is often referred as a horror-fiction writer, but ". . . his later works-those of his stories belonging to the Cthulhu Mythos-attempted to develop a distinctive species of 'cosmic horror', employing premises drawn from SF: other dimensions, invasion by aliens, and interference with human cultural and physiological evolution. He tried to convey a sense that the Universe is essentially horrible and hostile to humankind by means of a distinctive prose style which extends by gradual degrees from a quasiclinical mode into passages of dense, highly adjectival description" (Clute, Nichols, 1993c: 736-737). In addition, Lovecraft's influence on the subsequent development of various sci-fi genres is evident. 
and therefore, from tens of millennia in terms of time, one should proceed to hundreds of thousands and even to millions of years (Haudry, 2014; Thiriet, 2001). For Lovecraft, such a mind-boggling scale of time measurement is, nevertheless, a futile attempt to order, to harmonize, and to mask the revealed darkness of time, suggesting a bland optimism in a situation where sheer horror would be a more adequate response.

The doctrine of the "awesome grandeur of the cosmic cycle wherein our world and human race form transient incidents" opens up, regardless of its truth or falsity, impressive perspectives for the artistic representing of the Other (other sentient beings, other worlds, etc.), including those completely unknown to contemporary science fiction. Indeed, from the point of view of this doctrine, the question is quite legitimate: is the Manvantara, in which we all reside, confined within our Solar System, or does it encompass the whole of the material universe? In other words, if we take some solar system that is very distant from us as an example, will it have a different Manvantara or the same type as ours? The humankind inhabiting the Globe may form only a tiny fragment of the "humankind" in the whole Universe, stretching to the scale of cosmic infinity. Each of these countless "fragments" of universal humanity is located around one particular star and on one particular planet, which finds itself in the same unique and specific conditions as the Earth does, each has its own psychology and anatomy (not necessarily the humanoid one). If the logic of the cosmic cycles unfolding is that of top-down degradation, then it follows that every mankind will belong to a different period of the cycle, to a "golden" or an "iron" age. In other words, it is possible to admit the existence of an infinite number of "extraterrestrial Manvantaras" unfolding within the space-time continuum. In this case, the "cyclical condition" of some planets will be reduced to the infra-human condition, while on the contrary, other planets will be the center of superhuman condition where their unfolding can take place in various directions. Lovecraft himself, referring to the doctrine of cosmic cycles, highlights its quantitative rather than qualitative aspect: it is important for him to focus the reader's attention on the fundamental incomprehensibility of ancient cycles, and to demonstrate the entire known history of mankind as only an insignificant moment in comparison to the scale of cosmic cycles. The infinity of space and time is contrasted with the finitude of the human mind:

The actual cosmos of pattern'd energy, including what we know as matter, is of a contour and nature absolutely impossible of realization by the human brain; and the more we learn of it the more we perceive this circumstance. All we can say of it, is that it contains no visible central principle so like the physical brains of terrestrial mammals that we may reasonably attribute to it the purely terrestrial and biological phaenomenon call'd conscious purpose; and that we form, even allowing for the most radical conceptions of the relativist, so insignificant and temporary a part of it (whether all space be infinite or curved, and transgalactic distances constant or variable, we know that within the bounds of our stellar system no relativistic circumstance can banish the approximate dimensions we recognize. (Lovecraft, 2013: 927-928) 
Only Lovecraft's imitators pay attention to the qualitative aspect of cosmic cycles, linking some of them to the emergence and dominance of the characters in his mythological pantheon. It should be noted that Lovecraft's fiction is so convincing that a considerable number of his fans are sure that the creator of Cthulhu and other ancient gods was indeed coming in contact with them by means of magical operations (Steadmen, 2015).

However, Lovecraft's heroes, faced with these manifestations of the ancient gods, hardly thought of drawing "Pythagoras' Trousers" in the sand. The point here is not that the representation of the Other takes on an obviously threatening form, since even in its milder versions (Weinbaum, 2008), the behavior of mysterious barrel-shaped creatures with tentacles and chains of eyes upon their bodies remains completely inexplicable. The question as to which of the cases described above by Husserl we are dealing with here (with a contradiction that we cannot yet grasp, or with a contradiction within reality itself) loses its meaning when confronted with such representations of the Other. These creatures probably have other mathematics ("one and one, two, yes, two and two, four, no"), but how is it possible?

For an explanation, one may turn to Kant's transcendental aesthetics with his decisive conclusion is that all our contemplations are possible only when combined with two a priori forms of our sensibility-space and time. These two forms, generated neither as a result of our experience nor as a reflection of real space, are independent of our senses, and time has the same degree of reality. These forms precede every possible experience in the sense that with everything we feel, we always feel as residing within some space and time. We cannot conceive of anything that would not take up any space and would not have any duration of existence. This, according to Kant, is the best proof that space and time, which we are dealing with, are "pure", i.e., transcendental forms of our sensibility. Since these forms precede every possible experience, they are the same ones for every human being, and serve as the basis for geometry (space) and arithmetic (time).

However, they are only universally valid for either human beings or for all living creatures whose a priori forms of sensibility are space and time. Kant, however, admits exceptions to this rule common to mankind: "For we cannot judge at all whether the intuitions of other thinking beings are bound to the same conditions that limit our intuition and that are universally valid for us" (1998: 160). The human mode of perceiving things is not binding for every sentient being; one can imagine creatures that have a pair of alternative a priori forms of sensibility, not space and time. In addition, there are possibly creatures having only one a priori form, or more than two forms. Obviously, for beings of this kind (Kant speaks of the "thinking being") human mathematics and its propositions will not have their universal validity and necessity they have for humans. No mutual understanding between a human and a thinking being of another constitution would be possible. SF authors just try to design and to study the chances for communications without any underlying forms of a priori synthesis with the means of artistic imagination. To support this argument, Wolfe suggests that "Since monsters symbolize the unknown, the encounter with the monster is often caused either by humans breaching the barriers that separate them from the monster's realm, or vice versa" (1979: 187). 
To the extent that the Other is indispensable for the individual to perceive himself as a human, the Other should be portrayed as distinctly inhuman. The differences between the Human and the Other should be manifest, and in this respect, the depiction of monsters by SF is more fruitful than that of alien humanoids differing from humans only by their position on the evolutionary staircase. Critics have observed that the signs of rotting flesh, often accompanying sci-fi descriptions of monsters (e.g., in the War of the Worlds by Herbert Wells), are intended to evoke not only a natural disgust in the reader (i.e., to emphasize the difference between the human and the Other), but also to inspire him with a subconscious superiority of a living being over a dying one (Kerslake, 2007).

\section{Is It Possible to Contact the Other? Ray Bradbury as a Postcolonial Writer}

We shall call another way of representing the Other as "vibrational", drawing on an argument formulated by Guenon (2004: 157-158) in his criticism of occult theories of the first half of the twentieth century:

If we admit the theory that explains all sensations by more or less rapid vibratory
movements, and if we consider a chart showing the vibrations per second corre-
sponding to each kind of sensation, we are struck by the fact that the intervals
representing what our senses transmit to us are very small in relation to the whole.
They are separated by other intervals wherein nothing is perceptible to us; and fur-
ther, it is not possible to assign a determinate limit to the increasing or decreasing
frequency of the vibrations, so that we must consider the chart as subject to prolon-
gation on both extremes by indefinite possibilities of sensations, which for us cor-
respond to no actual sensation ... If such beings are of such a nature that nothing
which provokes sensation in us provokes sensation in them, then so far as we are
concerned these beings are as if they did not exist, and conversely. Even if they were
at our side we would be no better off for it, and probably would not even perceive
their presence, or in any case would probably not recognize them as living beings.

One of its most striking examples is The Martian Chronicles by Ray Bradbury (1979). The earthlings and the Martians commit strange encounters that cannot be conceived in customary terms of a co-bodily presence (as the common pictures of the contacts of humans with the extraterrestrial monsters presuppose). Martians do vibrate as humans probably do vibrate for them, being here and nowhere at the same time. This theory, if we dare to follow Guenon in calling this argument a theory, explains many things in The Martian Chronicles; however, it is only partially significant for what follows in a sociological sense.

There is a direct historical and sociological explanation of the Other in The Martian Chronicles, where a fantastic extrapolation of North American colonization and the inevitable contact with the indigenous population comes to the fore. The Martian Chronicles might be interpreted as a collection of stories about the first Europeans who arrived in North America and then advanced to the West of the continent. The Indians turn into Martians, whereas the wilderness, which impressed the first settlers, turns into exotic 
Martian landscapes. Ultimately, The Martian Chronicles convey the uniqueness of the historical experience of exploring new territories, although they romanticize and mystify this experience at the same time, clearing it from the rudeness and cruelty entirely unacceptable in the twentieth century (Wolfe, 2001: 103-123). This interpretation is obvious, and Ray Bradbury has expressed both direct and indirect agreement with it in his many interviews. At the same time, the picture of a Martian civilization that is quite powerful, technologically advanced, and then, for reasons unknown to the colonizers, disappears (or ceases to make contact with them), bears very little resemblance to North American Indians and their traditional way of life.

It is well known that Ray Bradbury called The Martian Chronicles "an accidental novel", referring to the fact that their publisher, his namesake Walter Bradbury, refused to accept the stories for publication separately, proposing to compile them into the one volume. From the publisher's point of view, it would have been advantageous to do otherwise, but this random amalgamation explains the literary heterogeneity of The Martian Chronicles, as repeatedly pointed out by critics. At first glance, this heterogeneity is especially evident in the descriptions of the Martian civilization since the stories where the reader can get this fragmentary information (only eight out of the whole of twenty eight stories) ${ }^{8}$ contain obvious contradictions.

They tell the reader an "official" history of Martian civilization: having lost three expeditions to Mars (the circumstances of their loss are known only to the reader, but not to the characters of The Martian Chronicles), the fourth expedition discovers a huge number of deceased Martians in the homes of an abandoned Martian city who have died, as tests show, as a result of chickenpox. There are only a very small number of Martians (about 150) who have not been infected, so they try to avoid any contact with the colonists. If a reader accepts this version of events as true, there are only minor inconsistencies that can be easily ignored. For example, Sam Parkhill (The Off Season), fleeing from the Martians that chase him, kills some of them with pistol shots, but fails to notice that the dead are crumbling like some kind of glass constructions. In addition, the Martians inform Parkhill of the nuclear disaster on Earth before it has even occurred.

Perhaps the reader can find the clue to these eight plots in the Bradbury story called Night Meeting. Here, the hero of the story, the truck driver Thomas Gomez, meets a Martian on a mountain road. Although he talks to him, he cannot touch his hand and sees the stars through his body's outline. Here we see the above-described case of crossing the boundary values of perceptive intervals. Both are experiencing this borderline condition: “There was a thing to the light, to the hills, the road,' said the Martian. 'I felt the strangeness, the road, the light, and for a moment I felt as if I were the last man alive on this world'. 'So did I' said Tomas' (Bradbury, 1979: 92).

Thus, an encounter with the Other (a Martian) is possible only in a special "borderline" condition, and the reader sees that the meeting of Martians with the first three expeditions takes place in conditions close either to dreaming (the first expedition), or to

8. Ylla, The Earth Men, The Third Expedition,-And the Moon Be Still as Bright, Night Meeting, The Musicians, The Martian, The Off Season. 
madness and hallucinations (the second one), or to mass suggestion (the third). It should be noted that the inhabitants of the mental asylum, where the second expedition arrives, demonstrate the ability to create a sheer variety of creatures and objects (Ibid.: 32 ):

\begin{abstract}
A man squatted alone in darkness. Out of his mouth issued a blue flame which turned into the round shape of a small naked woman. It flourished on the air softly in vapors of cobalt light, whispering and sighing. The captain nodded at another corner. A woman stood there, changing. First, she was embedded in a crystal pillar, then she melted into a golden statue, finally a staff of polished cedar, and back to a woman. All through the midnight hall people were juggling thin violet flames, shifting, changing, for nighttime was the time of change and affliction.
\end{abstract}

It is the ability demonstrated by the Martians who came to Sam Parkhill (The Off Season). By following the members of the second expedition, the reader may assume that it is this ability that is the sign of deviation for the Martians. However, another assumption that this deviation is not the ability to create illusory creatures and objects, but the madman's inability to control them is also possible. Taking the astronauts wearing the identical overalls to be the captain's replicants, the Martians, first of all, see that these replicants do not disappear, do not change, and therefore are not controlled by their creator. In addition, the story of the third expedition induces an attentive reader to accept this version. The Martians create an illusory image of a typical American town assuming the appearance of the deceased relatives and friends of the crew members. After eliminating sixteen members from the third expedition, the Martians return to their authentic appearance.

Of course, we need a more detailed and comprehensive analysis of The Martian Chronicles finest details, including the so-called "apocrypha" inserted in the last "complete" edition approved by Ray Bradbury, to obtain solid conclusions. At this stage, we will just limit ourselves to assumptions: first, the Martians, unlike earthlings, had the ability to put themselves deliberately into the "borderline" conditions. This fact is also confirmed by the story of the first expedition, where Ill $\mathrm{K}$ kills astronauts in the dimension of reality as seen by his wife, Illa, in her dreams. Second, this ability was probably used as a weapon (the story of the third expedition) to protect themselves (The Martian).

Of course, if we consider The Martian Chronicles in terms of representing the Other, the Frontier Myth used in this book should come to the fore: "Bradbury's novel is, at heart, a critical rereading of the Conquest of the West, an attempt at giving a voice to the conquered people who Western literature so frequently frames as fundamentally 'Other'. The miniseries seems, on the surface, to be an attempt at conveying the same message, echoing many of the same story beats and capturing the same Conquest narrative" (Cote, 2013: 193). However, if the goal of The Martian Chronicles, like many other SF works, was to give a voice to the conquered people or to a minority, then Bradbury had to find a way to intrigue his audience. The image of the Martian civilization that he created, which kept its mystery away from earthlings, was the best means to achieve this.

One might suggest that our next logically consistent step would be an attempt to proceed from describing the two modes of representing the Other in sci-fi to the disclosing 
of their social or cultural and historical preconditions. In other words, it would be necessary to explain why the first mode, the scientist one, was predominant in Soviet science fiction, while the second, the anti-anthropic mode, inspired the authors from the United States and Great Britain to a much greater extent (although authors such as Isaac Asimov, Robert Sheckley, and the majority of contemporary hard sci-fi authors should, of course, be classified as scientists). However, this step requires a special study, which would be premature without the problematization of the topic of the Other in SF done in this article.

Another crucial aspect of the theme must be emphasized here. Since the publication of Edward Said's Orientalism in 1978, the concept of the Other, which had been the domain of various phenomenological theories in philosophy and sociology, has acquired distinct political connotations. This is due to the fact that the connection of this concept with the problem of identity came to the fore. Every "We" needs a "non-We" or an "Other" for its existence. Since the publication of Said's seminal book, post-colonial as well as de-colonial theories have come a long way, opening up great prospects for using their critical tools in the study of science fiction.

While drawing a demarcation line dividing what belongs and what does not belong to a given culture, it is crucially important to marginalize everything that resides outside of it. An opposition is necessary between the "We" and the "Other", which takes the guise of opposition between "Human" and "Inhuman". Voltaire's famous formula "If the Other did not exist, he should have been invented" is fully applicable to the figures of the Savage, the Alien, etc., as outlined in literature, the visual arts, the cinema, and in everyday life. When a culture imposes its perception of the Other on another one, it starts to see the Other not as he really is, but as he should be.

The Other therefore occupies a privileged place within science fiction. Sci-fi offers the broadest opportunities for the search for new forms of cultural identity, a search associated with the boldest experiments in politics, ethics, and anthropology. The SF connection with various forms of military, political, and cultural imperialism is highly problematic (although the fact that SF is born primarily in the mightiest world powers, such as the USA, USSR, Great Britain, and France is certainly not accidental). The exploration of the cosmic depths, the discovery of new planets, and the ambiguous desire to discover extraterrestrial sentient life-key themes of SF-can be viewed as a specific refraction of the political and cultural doctrines of imperialism.

This, perhaps, is explicated in Western SF through the exploitation of the theme of space commerce, whereas it is nowhere described in Soviet science fiction. However, even the altruistic missions of space explorers can be viewed as a depiction of religious missions of past centuries. Modern society cannot exist without defining itself through its relationship to the Other, whose figure, therefore, becomes an integral element of cultural development. To the extent that modern society changes its perception of what it is and what place it occupies in the world, the Other becomes a social reality whose function is to confirm (or refute) what this society expects of itself. Modern society needs its own 
distinction from the Other because it is through the perception of this distinction that it can guess either at the effectiveness of its growth or at the depths of its fall.

\section{References}

Bankovskaya S. (2007) Drugoi kak elementarnoe ponyatiye sotsial'noi teorii [The Other as a Basic Concept of Social Theory]. Russian Sociological Review, vol. 6, no 1, pp. 7587. (In Russian)

Bradbury R. (1979) The Martian Chronicles, New York: Bantam Books.

Clute J., Nichols P. (1993a) Anthropology. The Encyclopedia of Science Fiction, New York: St. Martin's Press, pp. 41-43.

Clute J., Nichols P. (1993b) Definitions of SF. The Encyclopedia of Science Fiction, New York: St. Martin's Press, pp. 313-315.

Clute J., Nichols P. (1993c) Lovecraft. The Encyclopedia of Science Fiction, New York: St. Martin's Press, pp. 736-737.

Cote P. (2013) De-alienating the Alien: The Limits of Empathy in NBC's The Martian Chronicles Miniseries, Jefferson: McFarland \& Co.

D’Amassa D. (2005) Encyclopedia of Science Fiction, New York: Facts on File.

Efremov I. A. (1971) Predislovie [Preface]. Larionova O., Ostrov Muzhestva [The Isle of Courage], Leningrad: Lenizdat, pp. 3-7. (In Russian)

Efremov I. A. (2016) Tumannost' Andromedy. Chas Byka [Andromeda Nebula; The Bull's Hour], Moscow: AST. (In Russian)

Gernsback H. (1926) A New Sort of Magazine. Amazing Stories, no 1, p. 3.

Guenon R. (1972) The Reign of Quantity and the Signs of the Times, Baltimore: Penguin Books.

Guenon R. (2004) The Spiritist Fallacy, New York: Sophia Perennis.

Gurevich G. (1968) Funktsia Shorina [Shorin's Function]. Anthologia sovetskoi fantastiki [An Anthology of Soviet Science Fiction], Moskow: Molodaya gvardia, pp. 287-326. (In Russian)

Harman G. (2012) Weird Realism: Lovecraft and Philosophy, Winchester: Zero-book.

Haudry J. (2014) Les origines de la conception indienne des âges du monde. Comptes rendus des séances de l'Académie des Inscriptions et Belles-Lettres, no 1, pp. 159-173.

Husserl E. (2001) Logical Investigations, Vol. 1, London: Routledge \& Kegan Paul.

Kant I. (1998) Critique of Pure Reason, Cambridge: Cambridge University Press.

Kant I. (2002) Critique of Practical Reason, Indianapolis: Hackett.

Kerslake P. (2007) Science Fiction and Empire, Liverpool: Liverpool University Press.

Lovecraft H. P. (2005) The Call of Cthulhu. Tales, New York: The Library of America.

Lovecraft H. P. (2013) Letter to Frank Belknap Long, 20 February, 1929. Joshi S. T., I Am Providence: The Life and Times of H. P. Lovecraft, New York: Hippocampus Press, pp. 927-928.

Mann G. (2001) The Mammoth Encyclopedia of Science Fiction, London: Robinson.

Martynov G. (1966) Spiral vremeni [Time Helix], Leningrad: Lenizdat. (In Russian) 
Mikhailovsky B. (1939) Fantastika [Fantastic Fiction]. Literaturnaya enciklopediya. T. 11 [Literary Encyclopedia, Vol. 11], Moscow: Khudozhestvennaya literature, pp. 584-586. (In Russian)

Neelov E. (2008) Eshche raz o zhanrovoj specifike fantasticheskoj literatury [Once Again about the Genre Specificity of Fantastic Literature]. Proceedings of Petrozavodsk State University, no 1, pp. 100-105. (In Russian)

Said E. W. (1978) Orientalism: Western Conceptions of the Orient, London: Penguin.

Salnikov E. (2017) Fentezi i formirovanie mifologemy tolerantnosti sovremennogo mira [Fantasy and the Formation of Tolerance Mythologeme in the Modern World]. Values and Meanings, no 3, pp. 18-27. (In Russian)

Schutz A., Luckmann T. (1974) The Structures of the Life-World, London: Heineman.

Snegov S. (2010) Lyudi kak bogi [Men as Gods], Moscow: Ecsmo. (In Russian)

Steadmen J. L. (2015) H. P. Lovecraft and the Black Magickal Tradition, San Francisco: Weiser Books.

Thiriet G. (2001) Introduction a la cyclologie hindoue. La Regle d'Abraham, no 11, pp. 2643.

Weber M. (2008) Science as a Vocation. Max Weber's Complete Writings on Academic and Political Vocations, New York: Algora, pp. 17-21.

Wolfe G. K. (1979) The Known and the Unknown: The Iconography of Science Fiction, Ohio: Kent State University Press.

Wolfe G. K. (2001) The Frontier Myth in Ray Bradbury. Ray Bradbury (ed. H. Bloom), Philadelphia: Chelsea House, pp. 103-124.

Weinbaum S. (2008) The Martian Odyssey and Other SF, Los Angeles: Aegypan.

\section{Социальная проблематика Другого в научной фантастике}

\section{Владимир Быстров}

Доктор философских наук, профессор Института философии Санкт-Петербургского государственного университета

Адрес: Университетская набережная, д. 7/9, г. Санкт-Петербург, Российская Федерация 199034

E-mail:vyb83@yandex.ru

\section{Владимир Камнев}

Доктор философских наук, профессор Санкт-Петербургского государственного университета Адрес: Университетская набережная, д. 7/9, г. Санкт-Петербург, Российская Федерация 199034 E-mail: kamnevvladimir@yandex.ru

В статье научно-фантастическая литература рассматривается в связи с некоторыми аспектами такой социологической и антропологической проблемы, как репрезентация Другого. При всем многообразии жанров научной фантастики исследователь всегда имеет дело либо с непосредственной репрезентацией Другого (существа, отличного от актуального человека), либо с опосредствованной формой этой репрезентации, когда перед читателем или зрителем раскрывается Другой Мир, а через него и Другой в первоначальном смысле 
этого термина. Дано описание двух способов репрезентации Другого в научной фанастике, которые условно обозначены как сциентистский и анти-антропный. Сциентистская репрезентация конструирует исключительно рациональные условия отношения к Другому, и ее историко-философским коррелятом может рассматриваться учение Э. Гуссерля об истине, одинаковой для людей, не-людей, ангелов и богов. Анти-антропная репрезентация, более привлекательная для авторов научной фантастики, берет свой исток в характерном для человека модерна переживании «расколдовывания» мира, в частности, в трагическом ощущении несоизмеримости конечного человеческого существования и бесконечных космических бездн. Историко-философским коррелятом анти-антропной репрезентации Другого можно считать учение И. Канта об априорных формах чувственности, которые у других мыслящих существ могут быть иными, и поэтому модель отношения к Другому не может строиться на рациональных основаниях. В качестве литературного примера, где обнаруживаются эти два способа репрезентации Другого, рассмотрены «Марсианские хроники» Рэя Брэдбери, которые, с одной стороны, представляют собой фантастическую экстраполяцию колонизации Северной Америки и неизбежных контактов с коренным населением. С другой стороны, в «Марсианских хрониках» изображена могущественная и технически развитая марсианская цивилизация, которая по непонятным причинам исчезает, или перестает контактировать с колонизаторами. Комбинирование этих двух способов репрезентации Другого позволяет Брэдбери эффективно романтизировать и мистифицировать уникальный исторический опыт колонизации, модифицировать миф о фронтире.

Ключевые слова: научная фантастика, Другой, монстр, репрезентация, сциентизм 